\title{
难民危机下的儿童安全游乐空间 \\ SAFE PLAY SPACES \\ FOR CHILDREN \\ IN EMERGENCY CONTEXTS
}

\section{1 叙利亚难民危机}

目前, 约有 150 万叙利亚难民生活在黎巴嫩, 使该国成为人均收 容难民最多的国家 ${ }^{[1]}$ 。这一数字由多个政府及联合国机构估算得出, 并非该国难民的实际人数。在914 648名已于联合国难民署登记的叙 利亚难民中, 约 $56 \%$ 为 18 岁以下的儿童 ${ }^{[2]}$ 。

为应对这一危机，多个联合国机构、国家政府，以及国际 NGO 已提供了包括建造非正式帐篷定居点在内的人道主义援助, 但这些 定居点并不足以为儿童的成长提供具有活力且安全的氛围（图1）, 那些生活在黎巴嫩城市中的难民儿童也面临着同样的问题。

\section{2 项目背景}

2014年, 三名刚刚从伦敦大学学院 (UCL) 毕业的建筑师和城 市规划师创立了CatalyticAction非盈利设计工作室, 希望运用自己的 专业知识和技能帮助难民应对危机。该工作室的联合创始人及设计 总监里卡尔多 - 卢卡 - 康迪表示: “我们想要探索如何通过建筑应 对脆弱社区所面临的挑战，并改善现有的人道主义实践。”

中图分类号 / TU986.2, TU29, D815.6 文献标识的/

里卡尔多·卢卡 · 康迪

CatalyticAction非盈利设计工作室联合创始人及设计总监

摘要

本文回顾了CatalyticAction设计工作室为 寄居于黎巴嫩的叙利亚难民儿童建造“微笑游乐 场”这一特殊空间的整个过程, 旨在探索如何通 过建筑应对脆弱社区所面临的挑战, 并改善现有 的人道主义实践。文章首先介绍了叙利亚难民危 机, 以及这一背景与微笑游乐场设计理念的关 联, 随后探讨了游乐场建造过程中的社区参与模 式，以及项目期待传达的设计价值观，包括使用 本地材料和本地劳动力以振兴当地经济。最后, 文章介绍了近年来CatalyticAction设计工作室针 对难民儿童的其他项目。通过5年多的社区合作与 在地实践, 设计团队证明了游乐空间对于提升弱 势群体福祉的重要作用, 在制定应急响应方案时 应对此予以更多重视。

\section{关键词}

儿童; 难民; 游乐场; 设计; 叙利亚; 黎巴嫩
Riccardo Luca CONTI*

Co-founder and Director at CatalyticAction

*Corresponding Author

Address: 48 Rainham Road NW10 5DJ, London. UK Email: riccardo.luca.conti@catalyticaction.org

\section{ABSTRACT}

The article reflects on the IBTASEM playground project, looking at the process that led CatalyticAction's co-founders to implement this particular space for Syrian refugee children in Lebanon, and aiming at understanding how architecture can respond to the challenges that vulnerable communities face, and how it could improve existing humanitarian practices. The article begins with a description of the Syrian refugee crisis and how it links to the concept behind the IBTASEM playground project, and then explores the participatory process that CatalyticAction used to implement the project and the design values including using local materials and local labors to promote the local economy. Lastly the article introduces other projects targeting refugee children CatalyticAction has carried out in recent years. After over 5 years of practice working with communities, CatalyticAction has proven that the play space has a massive role in improving the wellbeing of vulnerable populations and it should not be overlooked when planning for emergency response.

\section{KEYWORDS}

Children; Refugees; Playground; Design; Syria; Lebanon 
在黎巴濑贝卡谷地非正 式帐篷定居点中玩要的 孩子们

Children playing in an informal tented settlement in the Bekaa Valley, Lebanon.
设计师开展工作的第一步是与正在黎巴嫩直接应对叙利亚难民 危机的 NGO进行交流。同时, 通过对当地难民社区进行会谈与走 访, 设计师充分了解了这些难民的想法, 并基于那些已达成共识的 需求着手构思可能的设计解决方案。

由于大多数叙利亚难民为儿童, 因此Catalytic Action设计工作 室决定开展一个专门针对儿童的项目。设计团队一来到位于黎巴嫩 的非正式帐篷定居点, 即发现这里的儿童安全活动空间极为匮乏, 于是提出了众筹资金建造一座游乐场的想法一一这不仅能为儿童 提供安全的活动空间, 还可保障他们充分享有游戏的权利, 并通 过玩要进行社交互动。作为工作室的试点项目, 该项目被命名为 IBTASEM, 其在阿拉伯语中意为 “微笑”。

\section{3 社区参与}

在项目构想成形之后, 设计团队便着手将其转变为现实。由 于CatalyticAction设计工作室联合创始人极为重视项目全程的社区 参与, 这一理念体现在工作室的每个项目中, 旨在充分彰显本土文 化、利用当地居民的知识与技能，并回应他们的需求以及愿景。 “微笑游乐场”项目也采取了这一模式，并于2015年初启动。

设计团队为社区内的难民儿童举办了一系列设计参与活动, 引 导他们为游乐场空间的构想贡献创意。孩子们与设计团队分享了他 们曾经的游戏经历，并通过绘画展示了他们对于游乐场游戏或设施 设置的构想（图2）。此外，设计团队还观察了孩子们现有的游戏习 惯，以使游乐空间能够更好地满足他们的使用需求。这一过程可使

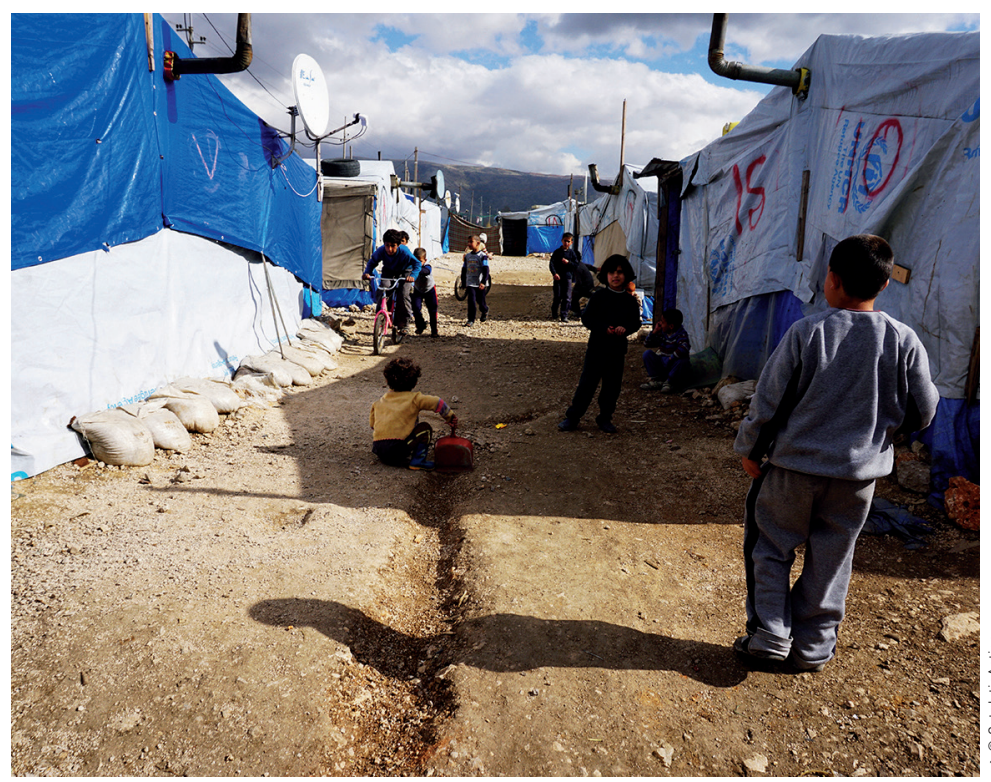

孩子们对亲自参与设计的空间产生主人翁意识，也为设计师和其他 项目参与者提供了了解儿童活动的机会（图3）。

\section{4 设计价值观}

CatalyticAction设计工作室希望在设计过程中传递其价值观，包 括利用本土材料促进当地经济发展一一虽然微笑游乐场项目针对的 是叙利亚难民儿童, 但建造材料均购买于黎巴嫩当地。这也使得设 计团队可以与当地小型企业和工厂合作，并有机会向他们介绍这些 项目, 从而提升当地的社会凝聚力。事实证明, 这些企业主们都对 项目本身表现出浓厚的兴趣, 并积极响应亲手建造游乐场、制作游 乐设施的想法，使项目不必通过大型国际制造商购买成品。

此外, 项目的建造过程还雇用了本地劳动力, 这为当地人提供 了学习先进配件组装技术的宝贵机会, 参与项目的设计师和工程师 也能从中受益。例如，负责项目结构工程的奥雅纳工程顾问公司意 大利分公司为该项目设计了使用本地材料制作、可由当地劳动力在 现场完成组装的全套连接件, 其中一种定制化的搁栅针件无需特殊 的焊接技能即可组装, 当地的焊接工人能够轻松胜任（图4)。一旦 这位焊工学会了如何组装这种组件, 就可以在未来的其他项目中继 续应用这一技能。

\section{5 微笑游乐场}

2015年夏天，在设计团队、当地社区以及国内外志愿者的共同 努力下，微笑游乐场在位于黎巴嫩贝卡谷地的巴尔-伊莱亚斯镇开始 建造。该镇叙利亚难民人数众多, 距叙利亚边境仅 20 分钟车程。

游乐场设计旨在为当地的叙利亚难民儿童提供多种游戏体验, 包括想象游戏 (例如儿童可以利用游乐场中的 “汽车操作面板” 模 拟开汽车) 、角色扮演游戏、各种运动游戏, 以及寓教于乐游戏 (图5)。这些游戏内容是在项目之初经过儿童、教师, 以及参与该 项目的NGO核心人员共同讨论确定的。

因此, 这个游乐场不仅是一个游戏空间, 还是一处学习空间, 也是一个可与朋友分享游戏经验的儿童成长空间。游戏在儿童成长 中发挥着极为重要的作用, 但在难民危机下常常被忽视。微笑游乐 场的建成成功引发了一些国际组织对此问题的关注, 还揭示出如果 儿童有机会在进行其他活动前后进行某些游戏活动, 他们总体上也 会更乐于参加这些活动。事实上, 当学校设有可供玩要的操场或教 师以游戏的方式进行教学活动时, 通常会取得更好的教学效果。

在微笑游乐场的落成典礼上, CatalyticAction设计工作室邀请花 式篮球组织 Da Move为孩子们提供了为期两天的篮球培训, 这让孩子 们有机会以一种有趣且有教育意义的方式使用该游乐场。落成典礼 当天, 孩子们在操场上尽情玩要, 同时欣赏 Da Move精彩的篮球表 演, 一些孩子也展现了出色的篮球技艺和运动天赋 (图6,7)。此 

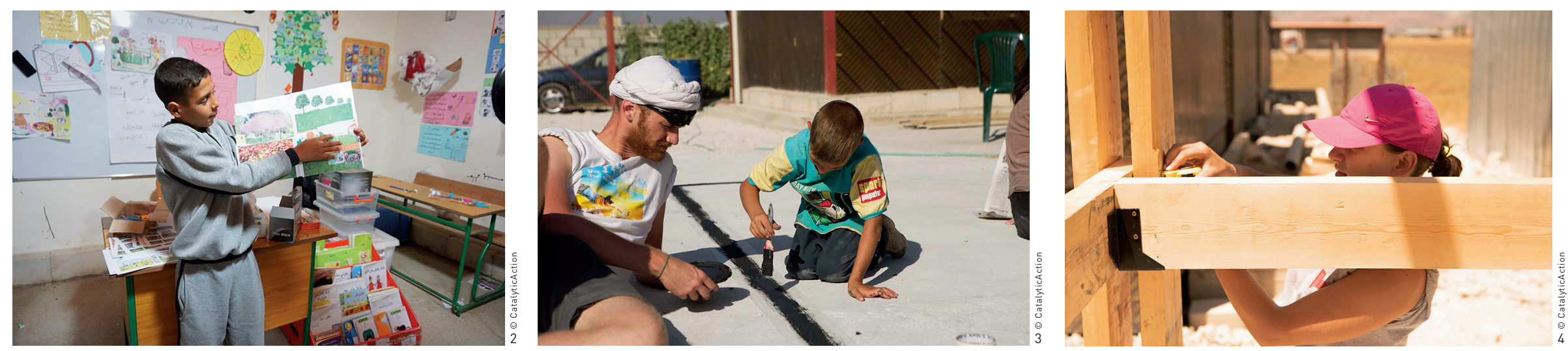

外, 黎巴嫩游戏权利组织向学校捐赠了篮球, 并对三名教师进行了 游戏教学培训, 以最大程度地利用该游乐场。

与其他组织进行合作是CatalyticAction设计工作室顺利开展工作 的基本保证, 因为每个组织都掌握着特定的专业知识与技能, 只有 将其进行融合才能确保项目的成功。致力于教育和儿童保护的 $\mathrm{NGO}$ 是工作室合作的首选对象（图8）。

受微笑游乐场概念和设计的启发, 黎巴嫩和叙利亚的其他组织 也按照相同的设计原则建造了 5 个项目，其中两个位于叙利亚。

直到今天，微笑游乐场仍在服务于当地儿童。设计团队最近遇 到了一位母亲, 她的儿子曾在 2015 年参与了游乐场的设计过程。她 表示, 即使在 5 年后, 他仍然可以愉快地回忆起那段快乐时光, 该项 目也给她留下了深刻印象。

\section{6 其他工作}

除了微笑游乐场，近年来CatalyticAction设计工作室还针对难民 儿童开展了许多其他工作 ${ }^{\mathbb{1}}$ 。2016年, 设计团队在黎巴嫩迈尔季建 造了杰勒赫尔难民儿童学校。该项目回收利用了2015年米兰世博会
“救助儿童” 展馆的结构框架, 于 2017 年获得拉法基豪瑞可持续建 筑奖, 并人围2019年阿迦汗建筑奖。

2017 2018年, CatalyticAction设计工作室开始深人开展旨在促 进社会凝聚力的项目, 其中包括在黎巴嫩甘泽镇设计大型游乐场, 以及与 “战争儿童” 组织荷兰分会合作建造各种教育类设施。这些 项目尽量对现有设施进行回收改造, 避免盲目开展新建工程, 以实 现节约建造成本和改善现有基础设施的双重目标, 最终使难民和本 地收容社区都能从中受益。

2019年, CatalyticAction设计工作室开始与UCL合作开展多 个研究项目, 以加深对其项目所在地的了解。2019年底, 通过与 意大利特雷-德-霍姆斯非盈利组织和国际阿梅尔协会的合作, CatalyticAction设计工作室在黎巴嫩建成了当地首批（4个）包容性 游乐场项目（图9）。这些游乐场允许残疾儿童与健全儿童在一起玩 要, 旨在保障所有儿童的游戏权益。

截至目前, CatalyticAction设计工作室已在中东地区建造了26个 服务于最为脆弱的社区的游乐场项目。通过 5 年多的社区合作与在 地实践, 设计团队证明了游乐空间对于提升弱势群体福祉的重要作 用，并呼吁在制定应急响应方案时对此予以更多重视。LAF
请访问CatalyticAction 非盈利设计工作室官 方网站了解更多相关 工作

2. 一名儿童正在展示他 对微笑游乐场的愿景

孩子们参与游乐场的 建造。

4. 由于当地买不到掐棚 针件成品, 因此需要 人工组装。

5. 微笑游乐场剖面图呈 现了不同的游乐空间

2. A child presenting his vision for the IBTASEM playground

3. Children took part in the implementation of the playground.

4. Joist hangers were not available locally so they had to be fabricated.

5. Section of the IBTASEM playground showing the different play spaces

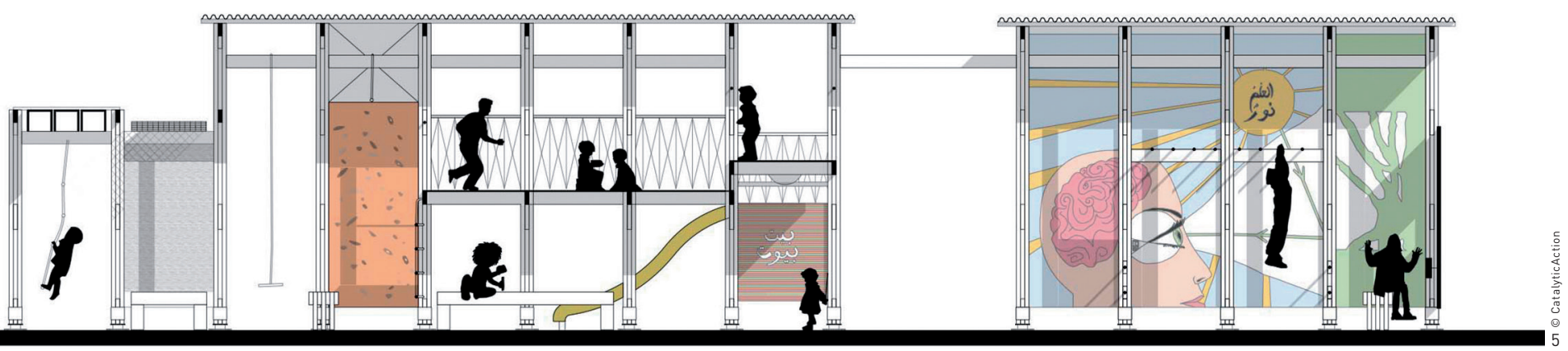




\section{The Syrian Refugee Crisis}

An estimated 1.5 million registered and unregistered Syrian refugees currently live in Lebanon, making it the country that hosts the largest number of refugees per capita ${ }^{[1]}$. The total number is based on different estimates conducted by the government and United Nations (UN) agencies, and does not accurately represent the exact number of refugees in the country. 914,648 Syrian refugees are registered with United Nations High Commissioner for Refugees (UNHCR), of which roughly $56 \%$ are children below the age of $18^{[2]}$.

In response to this crisis, the UN agencies and different nation states and international NGOs have delivered some supports like informal tented settlements, but they do not provide a vibrant and safe atmosphere for children to grow up in (Fig. 1). This is also valid for most urban contexts where refugees are living in Lebanon.

\section{Early Days}

In 2014, a team of three architects and urban planners, who recently graduated from the University College London (UCL), decided to take initiative and challenge themselves to apply their knowledge and skills to respond to this crisis. Then they founded CatalyticAction design studio. Riccardo Luca Conti, the co-founder and director, said that they "wanted to understand how architecture can respond to the challenges that vulnerable communities face, and how it could improve existing humanitarian practices."

The first step was to speak with NGOs who were already established in Lebanon and directly responding to the Syrian refugee crisis. Through various meetings and interviews with communities in Lebanon, designers collected enough insights to start thinking about possible design solutions for some of the needs identified.

As the majority of Syrian refugees are children, CatalyticAction decided to work on a project addressing this group in specific. While visiting the informal tented settlements in Lebanon, it was almost immediately clear how there is a lack of safe spaces for children. From this observation the idea of raising funds to build a playground was born. A playground would have the potential to not only provide a safe space but also offer a space where children could exercise their right to play and interact with each other through playing. The project was the pilot project for CatalyticAction and it was named IBTASEM, which means "smile" in Arabic.

\section{Community Participation}

Now that the idea for a project was born, CatalyticAction team had to work on how to bring that idea to reality. One aspect that CatalyticAction's co-founders strongly value is community participation in all the steps of a project. For this reason, in every project CatalyticAction conducts an extensive participatory approach with the local community to reveal and enhance community knowledge, skills, culture, needs, and visions. The same approach was used for the IBTASEM playground project in early 2015.

Several activities were conducted with Syrian refugee children during which they contributed to the ideation of the playground spaces. Children shared with design team their memories of play and drew the games or features that they wished to include in the playground (Fig. 2). Design team also observed the existing play practices in order to enhance some of those through the spaces that the playground will offer. Engaging children in design activities allows them to build a sense of ownership towards the spaces that they are designing and will then use. Furthermore, engaging in meaningful participation with final users also offers a learning opportunity for the designers and those who facilitate activities (Fig. 3).

\section{Design Values}

CatalyticAction's co-founders were also eager on promoting certain values as part of the design process. Using local materials to promote the local economy was one of these values. This was particularly important considering another aspect that the project addressed was social cohesion. This was possible through the selection of local materials because even though the project was targeting Syrian refugee children, the materials used to build the playground were purchased from small Lebanese local businesses. This allowed the team to engage with small businesses locally and inform them about the project. Ultimately, they all showed interest in the project and in the innovative idea of fabricating a playground and play items rather than buying them ready off the shelf from international manufacturers.

Similarly, labor was also hired locally. This was important as it gave the opportunity for people who took part in the construction of the playground to learn about new techniques and methods to fabricate certain components. This was also a learning experience for the 
designers and engineers involved in the project. For example, the structural engineering that was done by Arup Italia had to follow the criteria of using local labor and local materials for all the components of the structure. This meant that all joining components had to be fabricated locally using the materials available and the knowledge and skills of the labor. In the IBTASEM playground, this was translated into custom-designed joist hangers which were fabricated locally by a welder and did not require any particular welding skill (Fig. 4). This particular welder learned how to fabricate such a component, which could also be used in other future projects he will be commissioning.

\section{The IBTASEM Playground}

Ultimately in the summer of 2015 , the design team together with the local community and a team of national and international volunteers implemented the IBTASEM playground in the town of Bar Elias located in the Bekaa Valley in Lebanon, which is a region with a very high presence of Syrian refugees. The Syrian border can be reached in just 20 minutes by car from Bar Elias.

The playground design aimed at offering multiple play experiences for Syrian refugee children: imaginative play (for example, "car panel" in the playground could be used by children to play acting as they were driving a car), role play, active play, and educational play (Fig. 5). These were identified during the participatory assessment conducted in early 2015 , including opinions from children, teachers, as well as key staff members of NGOs supporting this project.

The playground was therefore conceived not only as a space to play but also a space to learn, and a space to grow up by sharing play experience with friends. Play has a fundamental role in child development but it is often overlooked in emergency contexts. By implementing the IBTASEM playground, CatalyticAction moved the attention of several international organizations to the importance of play spaces for children affected by displacement. The IBTASEM playground also showed how children were overall happier to take part in other activities, if they had the opportunity to play before and after doing such activities. In fact, school performance is often improved when children have a playground at school or the teaching activities are conducted in a playful way.

For the IBTASEM playground inauguration, CatalyticAction partnered with the basketball freestyle group Da Move to provide a two-day training to the children. This presented a great opportunity for the children to use the playground in a fun and educational way. The inauguration day was a celebration of the day and all the children were able to play freely in the playground, as well as enjoying a basketball performance by Da Move and the talents and skills of some of the children (Fig. 6, 7). Right to Play Lebanon supported the project by donating basketballs, as well as providing training for three teachers on how to use play for education, therefore maximizing the use of the playground space.

The collaboration with other organizations is a
6. 在微笑游乐场尽情玩要 的孩子们

7. 在游乐场的落成典礼上 与Da Move花式篮球组 织共同进行篮球表演的 孩子们

6. Children playing in the IBTASEM playground

7. Children performing with Da Move during the playground inauguration
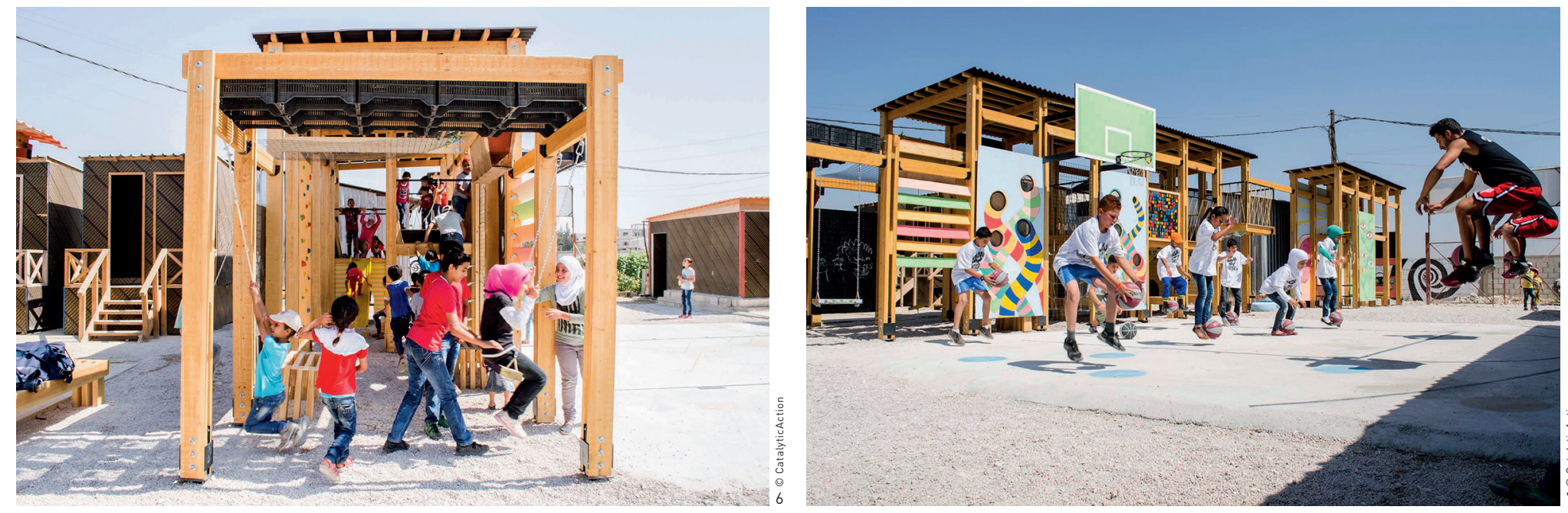
(1) For more information about CatalyticAction's work, please visit it official website.
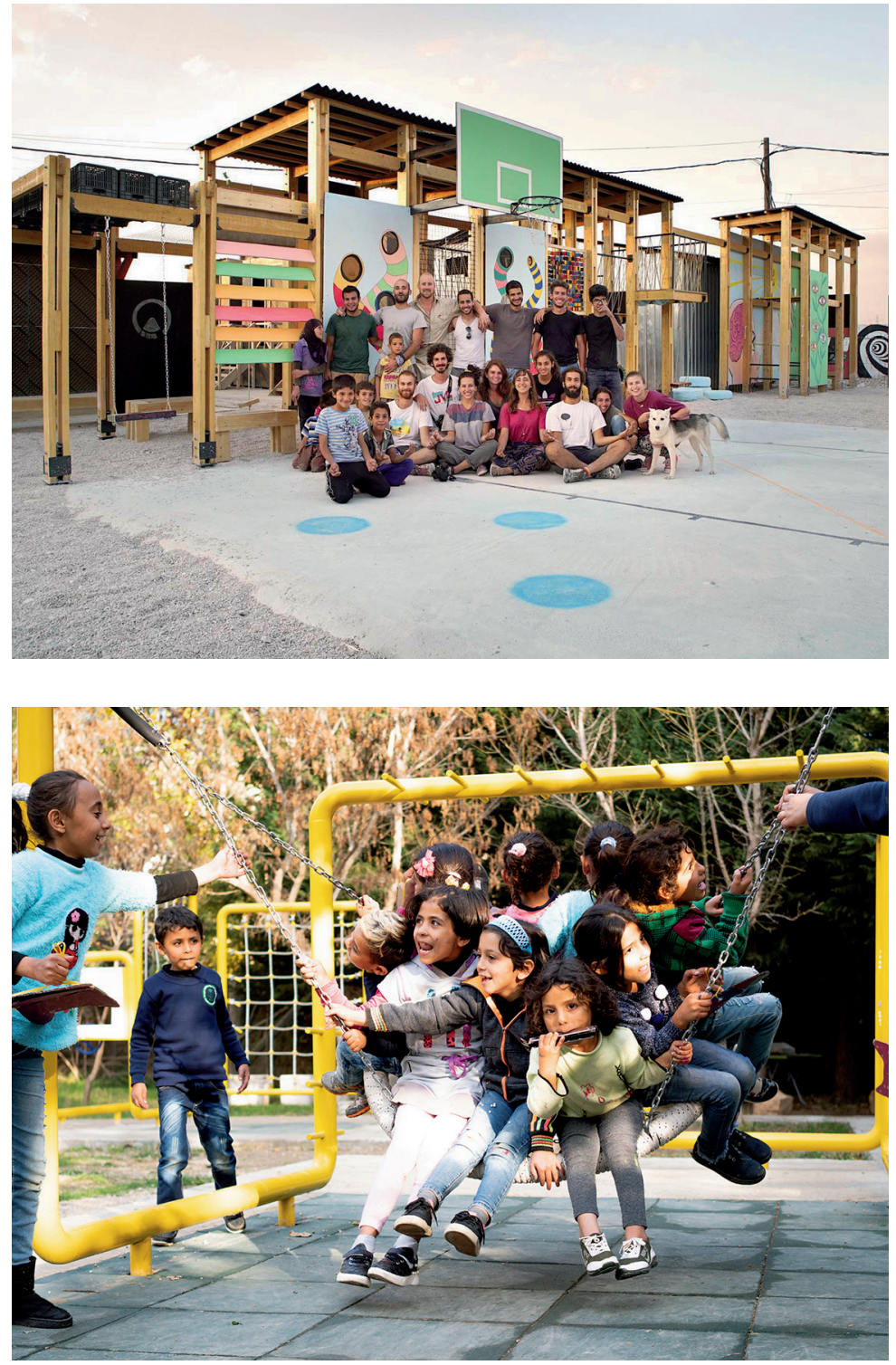

建造微笑游乐场的志愿 者团体

9. CatalyticAction设计工作 室于2019年在黎巴嫩建 造的包容性游乐场

8. The team of volunteers who built the IBTASEM playground

9. An inclusive playgroun implemented in Lebanon by CatalyticAction in 2019 This is because each organization brings a specific set of expertise and it is only through the merging of all these collaborative knowledge and skills that the projects are successful. CatalyticAction often partners with NGOs that work on education and child protection (Fig. 8).

Other organizations in Lebanon and Syria were inspired by the concept and design of the IBTASEM playground. This led to 5 projects being implemented following the same design principles. Two of these projects have been implemented directly in Syria.

Until today the IBTASEM playground is used by children in Bar Elias. The design team recently met the mother of one of the children who took part in the design process in 2015. She remembered the project very well as her son was very happy about it and he still remembers it with joy even after 5 years.

\section{Other Projects}

Besides IBTASEM, CatalyticAction has carried out many other projects targeting refugee children in recent years ${ }^{(1}$. In 2016 CatalyticAction implemented the Jarahieh School project in Al-Marj, Lebanon. The school was built through the adaptive reuse of the structure from the Expo 2015 pavilion of Save the Children. The project was awarded the LafargeHolcim Awards for Sustainable Construction in 2017 and shortlisted for the Aga Khan Award for Architecture (2017 - 2019 cycle).

In 2017 2018, CatalyticAction started working intensively on projects to promote social cohesion. These included a large playground in the town of Ghazze, Lebanon, and different educational facilities in partnership with War Child Holland. The strategy on many of these projects was to reuse existing facilities rather than building new ones from scratch. This was done to reduce implementation costs and improve existing infrastructure, which would benefit both refugee and host communities.

In 2019, CatalyticAction began working on multiple research projects in partnership with UCL. The research aimed at strengthening the knowledge on the context where CatalyticAction operates. At the end of 2019, CatalyticAction implemented the first 4 inclusive playgrounds in Lebanon (Fig. 9). These projects, done in partnership with Terre des Hommes Italy and Amel Association International, promote the right to play for all children, including those with disabilities. The playground spaces allow children to play together rather than offering separate play spaces for children with and without disabilities.

CatalyticAction has implemented 26 projects in the Middle
East, targeting the most vulnerable communities. After over 5 years of practice working with communities, CatalyticAction has proven that the play space plays a massive role in the wellbeing of vulnerable populations and it should not be overlooked when planning for emergency response. LAF

[1] The Government of Lebanon and the United Nations. (2019, January). Lebanon Crisis Response Plan 2017-2020. Retrieved from https://reliefweb.int/sites/reliefweb.int/files/resources/67780. pdf

[2] UNHCR Operation Portal Refugee Situations. (2020, January 31). Syria Regional Refugee Response. Retrieved from https://data2.unhcr.org/en/situations/syria/location/71

\section{REFERENCES}

